\title{
Emotional Stability and Perception of Job Security in the Services Sector in Malaysia
}

\author{
KAMARUL ZAMAN AHMAD \\ Faculty of Business and Accountancy \\ University Malaya \\ NOR KHASIMAH ALIMAN \\ NURUL SHANAZ AHMAD MAHDZAN \\ MARIA AZLINA KAMARUDIN \\ CHOW YEE PENG \\ TUSHA NANDITA \\ MBA Students \\ University Malaya
}

\begin{abstract}
Research pertaining to the perception of job security has focused primarily on attitudinal (e.g. job satisfaction), behavioral (e.g. employee turnover), and health outcomes, while research in the area of emotional stability has largely focused on attitudinal and social consequences. However, there appear to be no reported studies that have examined the relationship between emotional stability and the perception of job security in different industries within the Malaysian context. Data from 255 employees in the information technology, financial services and education industries were collected and analyzed. Results suggest that respondents in the education industry are more stable in the emotional dimension compared to those in the finance industry and that respondents in the education sector perceive job security to be higher compared to those in the finance and IT industries. In all three industries, emotional stability was significantly associated with perception of job security $(r=0.403)$. There is strongest correlation between emotional stability and perception of job security scores in the financial services industry. This suggests that in an industry that is unstable, respondents with higher emotional stability tend to perceive the same environment as more stable than those who have lower emotional stability.
\end{abstract}

\begin{abstract}
ABSTRAK
Kajian berkaitan dengan persepsi jaminan keselamatan kerja memberi tumpuan utama terhadap gaya sikap (contohnya kepuasan kerja), gelagat/kelakuan (contohnya tukar ganti pekerja) dan hal-hal yang berkaitan dengan kesihatan, manakala kajian dalam bidang kestabilan emosi sebahagian besarnya tertumpu kepada gaya sikap dan sebab akibat sosial. Walau bagaimanapun, tiada laporan penyelidikan yang mengkaji tentang perhubungan di antara kestabilan emosi dengan persepsi jaminan keselamatan kerja di dalam pelbagai industri di Malaysia. Data daripada 255 orang pekerja di dalam industri teknologi maklumat (IT), kewangan dan pendidikan telah dikumpul dan dianalisa. Keputusan kajian mencadangkan bahawa responden yang bekerja di dalam industri pendidikan lebih stabil emosinya berbanding dengan mereka yang bekerja di dalam industri kewangan dan responden di dalam sektor
\end{abstract}


pendidikan juga mempunyai persepsi yang lebih tinggi terhadap jaminan keselamatan kerja berbanding dengan mereka yang bekerja di dalam industri kewangan serta IT. Untuk ketiga-tiga industri, terdapat perhubungan yang ketara/signifikan di antara kestabilan emosi dengan persepsi jaminan keselamatan kerja ( $r=0.403)$ - yang paling kuat hubungannya ialah di dalam industri kewangan. Dengan ini dicadangkan bahawa jika industri adalah tidak stabil, responden yang mempunyai kestabilan emosi yang tinggi akan menganggp persekitaran yang tidak berubah-ubah sebagai lebih stabil berbanding dengan mereka yang mempunyai kestabilan emosi yang rendah.

\section{INTRODUCTION}

Organizational changes taking place in this new millennium have never been more dynamic. Corporate restructuring, mergers and acquisitions, and organizational downsizing are very common. Some industries seem to be more volatile than others. For example, the information technology industry is perceived to be one of the most volatile based on the rapid development of the technology related to it, with new innovations and enhancements frequently introduced. Mergers and acquisitions in the financial services industry, for example, create the perception that this industry is also volatile. On the other hand, the education industry can be argued to be the least volatile among the three industries based on the relative lack of innovations and changes. Whereas these are speculations made by many, it would be interesting to find out exactly what workers in such industries actually feel.

The perception of job security can be important for several reasons. Many studies have shown that job insecurity among employees leads to job dissatisfaction (Ashford, Lee, \& Bobko, 1989; Davy, Kinicki, \& Sheck, 1991), an increase in psychological distress (Dekker, \& Schaufeli, 1995; Probst, 2000), and higher reports of physical health outcomes (Dooley, Rook, \& Catalano, 1987; Kuhnert, Sims, \& Lahey, 1989; Roskies \& Louis-Guerin, 1990). Researches have also shown that employees with low perception of job security are more likely to have lower organizational commitment and to be involved in work withdrawal behaviors, which in turn often results in higher employee turnover (Ashford et al., 1989; Davy et al., 1991). However, although there are various studies conducted on the effects of perception of job security on employee attitudes, behaviors and physical and mental health outcomes, research on the relationship between emotional stability and perception of job security within the Malaysian context cannot be found.

There is also voluminous literature on emotional stability, where many of these studies have suggested the importance of emotional stability in selecting employees (Barrick, Dunn, Mount, \& Ones, 1995; De Fruyt, Lievens, \& Van Dam, 2001), assessing expatriates' adjustment to the host country (Caligiuri, 2000), determining social consequences (Bradley \& Young, 1998) and assessing of work-related attitudes (Temple, 1992). There was also research suggesting emotional stability as one of the personal characteristics attributable to general managers (Kotter, 1983).

\section{Purpose of the Study}

The purpose of the study was to unite these disparate areas of research by assessing the relationship between emotional stability and perception of job security in three different types of industries, that is, the information technology, financial services and education industries. This is in view of the fact that in today's economy, organizational changes are taking place in various industries. These include organizational restructuring, downsizing, mergers, acquisitions, etc. However, the rate of changes or degree of volatility varies across the industries. Thus the findings of this research may prove beneficial in understanding the relationship between emotional stability and perception of job security in the three chosen industries. 


\section{LITERATURE REVIEW}

\section{Industry Ranking}

The US Department of Commerce in its STATUSA (US Department of Commerce, 1998) ranked the computer software sector of the information technology industry in Malaysia as the most promising market. Telekom, (Telekom Publications, 2002) in promoting its Malaysian Information Industry Directory 2002/03 stated that Malaysia's Information Technology and Communication (ICT) industry is a fast growing market with the rapid expansion of e-commerce and an increasing demand for development of new hardware appliances, software and internet-related products and services. Deloitte and Touche (1992) in their survey on the job turnover of Chief Information Officers (CIO) found that in large companies, that is, companies, with revenue of US\$ 5 billion or more, the turnover rate was as high as 25 percent.

The World Trade Organization (1997), defines the financial services industry as an industry involved in insurance, brokerage, agency services, consultancy, actuarial services, banking, asset management, financial advisory, provision of financial information, trading of financial securities and foreign exchange, securities underwriting, settlement and clearing services, and other auxiliary financial services. King (1993) in her analysis of CIO turnover established that CIOs hired within the past one year could expect to stay in their current job position between 18 and 24 months only. This short tenure results from CIOs being lured to more lucrative positions offered by other companies. Radding, (1991) claims that perception of job security is the hallmark of university life as layoffs are rare. Universities rarely, if ever, merge, downsize or restructure.

\section{Perception of Job Security}

Employees are forced to focus on creating value in their jobs in order to secure their positions in the face of heightening competition and performance expectations in the world today (Bioscio, 2003). The continuous trends in changing work arrangement definitions and downsizing have left more employees fearing that they are facing the risk of losing their jobs.
Ugboro and Obeng (2001) in their studies on the effects of contracting in U.S. public transit organizations on employees' perception of job security have noted that outsourcing or the practice of contracting some parts of an organization's functions to another organization is usually followed by downsizing, internal structure alignment and workforce reduction that results in negative job experiences for both retrenched staff and the remaining survivors in the organization. This in turn has led to the heightening feelings of job insecurity among the employees. They also argued that when employees feel that the features of their jobs or entire jobs are threatened or feel that they are powerless are signs of feelings of job insecurity. They also suggested that some but not all job threats, threats to job features and powerlessness must occur for job insecurity to take place.

Greenglass, Burke and Fiksenbaum (2002) investigated the relationship between the impact of restructuring, job satisfaction, job insecurity and absenteeism in hospital nurses. Results showed that the impact of hospital restructuring had a direct effect on job insecurity and a negative effect on job satisfaction. Job satisfaction had a directly negative effect on absenteeism and a negative impact on job insecurity. In addition, findings showed that the relationship between the impact of hospital restructuring and job insecurity was mediated by job satisfaction. Brockner, Grover, Reed and Dewitt (1992) established the theory of layoff survivors' level of job insecurity should be highest when perceived threats to job or job features are high and perceived power and control is low; lowest when the perceived threat is low and perceived power and control is high; and moderate when both threat and control are high or both threat and control are low.

Greenhalgh and Rosenblatt (1984) proposed that there are two dimensions to perception of job security. The first dimension is the feeling of threats to a total job, which may include moving into a lower position within the organization, moving to another job at the same level within the organization, being laid-off temporarily or permanently or being forced into early retirement. The second dimension is the 
feelings of threats to job features, that is, when only certain aspects of one's job are threatened. These may include difficulty to get ahead in the organization, maintain one's current salary and receive pay increments or difficulty in accessing organizational resources. Perception of job security may also be measured in terms of feelings of powerlessness, that is, one's feelings of lack of power or inability to control events that affect them in the work situation or organization.

\section{Emotional Stability}

Emotional stability is one of the five main dimensions of personality that theorists have generally agreed on. These dimensions are part of a common description of personality traits suggested by other theorists. As cited in Ryckman (2004), these trait dimensions known as the 'Big Five' personality traits can be attributed to the works of Costa and McCrae (1992), John, Donahue and Kentle (1991) and Goldberg (1990a). The 'Big Five' personality traits are "extraversion", "agreeableness", "conscientiousness", "emotional stability" and "openness". "Extraversion" represents a preference for being around others and is associated with traits such as sociability, talkativeness and assertiveness. It reflects a personal orientation toward other people (Flynn, Chatman \& Spataro, 2001). "Agreeableness" describes the tendency to relate to others with tolerance, trust, and acceptance (Antonioni \& Park, 2001). According to Costa and McCrae (1992), and Barrick, Mount and Gupta (2003), people who score high on "agreeableness" are altruistic, friendly, sympathetic and eager to help others and they are more motivated to maintain positive relationships with other people. "Conscientiousness" means a tendency to focus on goals in an industrious, disciplined and dependable fashion. People scoring high in "conscientiousness" are dependable, orderly, selfdisciplined, hardworking and achievement striving (Digman, 1990; Watson, Clark \& Harkness, 1994). "Emotional stability" or "neuroticism" is the degree to which the individual is calm, self confident, and cool, versus insecure, anxious, depressed and emotional. People with low scores on "emotional stability" are anxious, hostile, envious, insecure, depressed, moody, and vulnerable (Costa \& McCrae, 1992; Goldberg, 1992b). Individuals who are low on "emotional stability" are especially stress prone, thus being more attracted to jobs that are relatively stress free (Barrick et al., 2003).

Understanding personality can be advantageous, as it can reflect how an individual relates to the social world (Mischel, Shoda, \& Smith, 2004). In relation to the work environment, personality data can be exploited to match people to the workplace and assist in the selection of personnel (Tett \& Murphy, 2002). An area of interest to researchers is the use of personality to predict job performance. The findings of a study by Salgado (2003) suggested that practitioners should use the Five-Factor Model (FFM)-based inventories in order to make personnel selection decisions, as opposed to using non-FFM-based inventories. The study also found that the scores for two personality traits, which are "conscientiousness" and "emotional stability", could be confidently used for predicting job performance. In an attempt to identify personality dimensions and other individual difference characteristics that would be predictive of job success, Riggio \& Taylor (2000) concluded that possession of communication and social competence and certain dimensions of empathy led to good prediction of job performance. The findings of this research were valid for a specific occupation, namely, the hospice nurse profession.

Stevens and Ash (2001) investigated the relationship between personality dimensions and preference of management style. It was found that individuals with higher levels of "agreeableness" and "openness" prefer more participative styles of management in a supervisor-subordinate relationship. On the other hand, individuals with low levels of these same two personality factors would prefer less participative styles of management. Understanding the personality of potential employees is thus advantageous in selecting individuals that fit in well with an organization's culture.

Tett and Murphy (2002) found that individuals prefer other people similar to themselves and those whom invite expression of one's own traits. Adapted to the workplace, this suggests that a co-worker's personality can 
influence others' preference for working with that person. Highly affiliated co-workers were specially preferred and highly dependent coworkers especially avoided. In summary, the findings of this study support the idea that people prefer those who let them be themselves. It also suggests that personality-based compatibility among co-workers may be more important in the prediction of job satisfaction and related outcomes such as organizational commitment and turnover. It would thus be interesting to find out whether the persons' environment can be operationalised in terms of the stability of the industry itself, rather than just their colleagues.

Judge, Higgins, Thoresen and Barrick (1999) investigated the relationship of the Big Five Personality traits and general mental ability with career success. General findings were that conscientiousness positively predicted intrinsic and extrinsic career success; neuroticism negatively predicted extrinsic success, while general mental ability positively predicted extrinsic career success. Extrinsic career success here refers to income and occupational status, while intrinsic career success refers to job satisfaction. In a similar finding, Lau and Shaffer (1999) also proposed that several personality traits, along with job performance and personenvironment fit, are determinants of career success.

Emotion in the workplace has increasingly become an issue of importance to organizational and management scholars (Miller, 2002). Barrick, Mount, Neubert and Stewart (1998), state that "extraversion" and "emotional stability" were associated with team viability through social cohesion. Salgado, (1997) states that "conscientiousness" and "emotional stability" are valid predictors across job criteria and for some occupational groups. Buss (1991) states that "emotional stability" is a universal adaptive mechanism enabling humans to cope with stress in their environment.

Dennis and Herring, (1999) state that during the past 10 years, more than 5 million families have been relocated one or more times by their employers. These relocations affect the "emotional stability" of household members, disrupt the careers of many members and require individuals to invest tremendous amounts of time to reestablish their lives. Astrachan (1995) investigated how layoffs or merger situations affect emotion and behavior. Anxiety is stimulated by the mere announcement that people in an organization are leaving and that the impact of this anxiety is expressed differently depending on the proportion of people staying in and leaving the organization. According to Fink (1988), merger planning is a period of uncertainty and insecurity for most people. Emotions generated by uncertainty and insecurity can result in altered behavior, decreased morale, reduced productivity, stress, illness and accidents.

\section{OBJECTIVES AND HYPOTHESES}

This research was conducted to investigate the relationship between emotional stability and perception of job security in general. It also attempts to identify whether there are differences of the emotional stability - perception of job security relationship among graduate employees working in the financial services, education and information technology industries. At the moment, there is no research conducted in Malaysia on this area. However, previous research by Salgado (1997) stated that conscientiousness and emotional stability are valid predictors across job criteria and for some occupational groups. In addition, Ugboro, and Obeng (2001) revealed that downsizing, internal structure alignment and workforce reduction creates feelings of job insecurity among employees. In a similar finding, Greenglass, Burke, and Fiksenbaum (2002), showed that the impact of hospital restructuring had a direct effect on job insecurity. Thus, the following hypotheses have been proposed for this research:

H1: There are significant differences in emotional stability scores between the different industry sectors.

$\mathrm{H} 2$ : There are significant differences in job security scores between the different industry sectors. 
H3: There is a positive relationship between emotional stability and perception of job security in general.

H4: The strength of the relationship between emotional stability and

perception of job security varies among graduate employees in the

financial services, education and information technology industries.

\section{METHOD}

\section{Research Instrument}

- The survey instrument was a three-page questionnaire. The questions relevant to this paper were found in three parts. The first part measured the perception of job security aspects. A total of 23 statements on a five-point Likert-type scale ranging from 1 (Strongly Disagree) to 5 (Strongly Agree) were used. For each of the statements, respondents were required to indicate their level of agreement to the statements. Thus, the minimum possible score was 23 , the maximum possible was 115 and the theoretical mid-point of the scale was 69 . The statements measured constructs that were deemed relevant to measuring perception of job security. Amongst the constructs measured were 'threats to the total job' (items 1 to 8), 'threats to job features' (items 9 to 20) and 'powerlessness' (items 21 to 23). All items were adopted from Ugboro and Obeng (2001). The Cronbach alpha coefficient obtained in this study was 0.8447 for the 23 items on perception of job security. These values meet the basic requirement of at least 0.7 as recommended by Nunnally (1978), suggesting a fairly high level of internal consistency in the responses.

In the second part, issues related to personality traits, emotional stability, were measured. A total of 14 statements were used. The respondents were also required to indicate their level of agreement to the statements based on a five-point Likert-type scale.Thus, the minimum possible score was 14 , the maximum possible was 70 , and the theoretical mid-point of the scale was 42. This part in particular attempted to see the stability of respondents' emotion. All items in this part were taken from the study of Tellegen (1982). The Cronbach alpha coefficient obtained in this study was 0.9132 for the 14 items on emotional stability also satisfying the recommendation by Nunnally (1978). The last part was designed to collect the demographic information of the respondents. The respondents were required to answer 10 questions (9 close-ended and 1 openended). Examples of the demographic variables were gender, ethnicity, marital status, education, income and job title.

\section{Sampling Procedure and Data Collection Method}

This study was carried out using the survey approach. This approach was used because field survey is one of the most common forms of data collection procedures used in many studies. Prior to the actual survey, a pilot test was conducted using 10 respondents. The results of the pilot test suggested that there would not be any difficulty for the respondents to respond to the questionnaire. The questionnaire was in English because the respondents were graduate employees holding various senior positions such as bank manager, IT engineer, system analyst, lecturer, tutor and administration staff.

Due to time and budget constraints, respondents were selected using non-probability convenience sampling procedure. Three hundred sets of questionnaires were distributed to the graduate employees from both sexes and working in the financial services, education or information technology industry in the Klang Valley. From the total number of questionnaires distributed, 255 questionnaires were completed and returned, giving a response rate of 85.0 percent. After screening the responses, 255 were retained for data analysis. The survey was conducted over a threeweek period through self-administration and email (13 of the respondents requested for and completed soft copy versions of the questionnaire). The results were analyzed using SPSS version 11.5.

\section{RESULTS}

\section{Profile of the Respondents}

Table 1 shows the demographic profile of the 
respondents. The sample of 255 responses consisted of 52.9 percent females and 47.1 percent males, majority of which were in the age group of between 25-35 years (67.8\%). Nearly 56.5 percent $(\mathrm{n}=144)$ of the respondents were Malays, 26.7 percent $(n=68)$ were Chinese and 14.9 percent $(n=38)$ were Indians and 2.0 percent $(n=5)$ from other ethnic groups. In terms of education level,
59.6 percent of the respondents were Bachelor degree holders, 22 percent were Diploma holders, 15.7 percent were Master degree holders and 2.7 percent were $\mathrm{PhD}$ holders. In terms of working sectors, 32.9 percent of the respondents were from the Education sector, 36.5 percent were from the Financial Services sector and 30.6 percent were from the IT sector.

Table 1

Respondents' Personal Characteristics

\begin{tabular}{|c|c|c|}
\hline Respondents' Characteristics $(\mathrm{n}=255)$ & Frequency & Percent \\
\hline \multicolumn{3}{|l|}{ Age (years): } \\
\hline Under 25 & 13 & 5.1 \\
\hline $25-30$ & 111 & 43.5 \\
\hline $31-35$ & 62 & 24.3 \\
\hline $36-40$ & 42 & 16.5 \\
\hline $41-45$ & 14 & 5.5 \\
\hline $46-50$ & 6 & 2.4 \\
\hline Above 50 & 7 & 2.7 \\
\hline \multicolumn{3}{|l|}{ Education Level: } \\
\hline Diploma & 56 & 22.0 \\
\hline Bachelor's Degree & 152 & 59.6 \\
\hline Master's Degree & 40 & 15.7 \\
\hline $\mathrm{Ph} . \mathrm{D}$ & 7 & 2.7 \\
\hline \multicolumn{3}{|l|}{ Ethnic Group: } \\
\hline Malay & 144 & 56.5 \\
\hline Chinese & 68 & 26.7 \\
\hline Indian & 38 & 14.9 \\
\hline Others & 5 & 2.0 \\
\hline \multicolumn{3}{|l|}{ Industry: } \\
\hline Education & 84 & 32.9 \\
\hline Financial Services & 93 & 36.5 \\
\hline Information Technology & 78 & 30.6 \\
\hline \multicolumn{3}{|l|}{ Marital Status: } \\
\hline Single & 93 & 36.5 \\
\hline Married Without Children & 15 & 5.9 \\
\hline Married With Children & 145 & 56.9 \\
\hline Divorced / Widower & 2 & 0.8 \\
\hline \multicolumn{3}{|l|}{ Gender: } \\
\hline Female & 135 & 52.9 \\
\hline Male & 120 & 47.1 \\
\hline
\end{tabular}


Table 2

Mean Scores of Emotional Stability and Perceptions of Job Security

\begin{tabular}{|c|c|c|c|c|c|}
\hline $\begin{array}{l}\text { Statistical } \\
\text { Analysis }\end{array}$ & $\begin{array}{l}\text { Theoretical } \\
\text { Mid-Point }\end{array}$ & $\begin{array}{c}\text { All } \\
\text { Cases } \\
(\mathrm{N}=255)\end{array}$ & $\begin{array}{l}\text { Finance } \\
(\mathrm{N}=93)\end{array}$ & $\begin{array}{c}\mathrm{IT} \\
(\mathrm{N}=78)\end{array}$ & $\begin{array}{c}\text { Education } \\
(\mathrm{N}=84)\end{array}$ \\
\hline Tot Emotional Stability & 42 & 46 & 45 & 46 & 48 \\
\hline Standard Deviation & Not Applicable & 8.82 & 8.28 & 9.09 & 8.89 \\
\hline Tot Job Security & 69 & 83 & 79 & 81 & 89 \\
\hline Standard Deviation & Not Applicable & 9.97 & 9.41 & 8.18 & 9.63 \\
\hline
\end{tabular}

When all cases were taken into account, this study revealed that the average score for emotional stability was 46 , that is, slightly higher than the theoretical midpoint of the scale which is 42 . The average score for job security was 83 , that is much more than the midpoint of the scale which is 69. Respondents from the education sector had the highest emotional stability and perceptions of job security scores. This was followed by the IT and lastly the finance industry. However, in order to find out whether the differences were statistically significant, tests of Anova were carried out. The tests revealed that the mean emotional stability score of respondents from the education sector was significantly higher than those in finance. The results are summarized in Tables 3(a). Thus partial support for Hypothesis 1 was obtained.

Anova tests also revealed that the mean job security scores of respondents from the education sector was significantly higher than those in finance and IT. However, there were no significant differences in scores between those in IT and finance for either emotional stability or job security scores. The results are summarised in Tables 3(b). Thus partial support for Hypothesis 2 was obtained.

Table 3a (i)

Tests of Anova: Emotional Stability (Education > Finance)

Descriptives

TOTEM

$95 \%$ Confidence Interval for Mean

N Mean Std. Deviation Std. Error Lower Bound Upper Bound Minimum Maximum

\begin{tabular}{lrrrrrrrr}
\hline Financial & & & & & & & & \\
Services & 93 & 44.7419 & 8.28291 & .85890 & 43.0361 & 46.44 .78 & 17.00 & 67.00 \\
Education & 84 & 48.1786 & 8.88638 & .96958 & 46.2501 & 50.1070 & 31.00 & 70.00 \\
IT & 78 & 46.1923 & 9.09411 & 1.02970 & 44.1419 & 48.2427 & 27.00 & 70.00 \\
& & & & & & & & \\
Total & 255 & 46.3176 & 8.81955 & .55230 & 45.2300 & 47.4053 & 17.00 & 70.00
\end{tabular}


Table 3a (ii)

Tests of Anova: Emotional Stability (Education > Finance)

\begin{tabular}{|c|c|c|c|c|c|}
\hline \multicolumn{6}{|c|}{ ANOVA } \\
\hline & $\begin{array}{l}\text { Sum of } \\
\text { Squares }\end{array}$ & df & Mean Square & $\mathrm{F}$ & Sig \\
\hline Between Groups & 523.027 & 2 & 261.514 & 3.426 & .034 \\
\hline Within Groups & 19234.243 & 252 & 76.326 & & \\
\hline Total & 19757.271 & 254 & & & \\
\hline
\end{tabular}

Table 3a (iii)

Tests of Anova: Emotional Stability (Education > Finance)

Multiple Comparisons

Dependent Variable: TOTEM

\begin{tabular}{|c|c|c|c|c|c|c|}
\hline \multirow[b]{2}{*}{ (I) Industry } & \multirow[b]{2}{*}{ (J) Industry } & \multirow{2}{*}{$\begin{array}{c}\text { Mean } \\
\text { Difference } \\
(\mathrm{I}-\mathrm{J})\end{array}$} & \multirow[b]{2}{*}{ Std. Error } & \multirow[b]{2}{*}{ Sig. } & \multicolumn{2}{|c|}{ 95\% Confidence Interval } \\
\hline & & & & & Lower Bound & Upper Bound \\
\hline \multirow[t]{2}{*}{ Financial Services } & Education & $-3.4366^{*}$ & 1.31505 & .010 & -6.0265 & -.8467 \\
\hline & IT & -1.4504 & 1.34136 & .281 & -4.0921 & 1.1913 \\
\hline \multirow[t]{2}{*}{ Education } & Financial Services & $3.4366^{*}$ & 1.31505 & .010 & .8467 & 6.0265 \\
\hline & IT & 1.9863 & 1.37375 & .149 & -.7192 & 4.6918 \\
\hline \multirow[t]{2}{*}{ IT } & Financial Services & 1.4504 & 1.34136 & .281 & -1.1913 & 4.0921 \\
\hline & Education & -1.9863 & 1.37375 & .149 & -4.6918 & .7192 \\
\hline
\end{tabular}

* The mean difference is significant at the .05 level.

Table 3b (i)

Tests of Anova: Job Security (Education > Finance; Education > IT)

TOT JOB

Descriptive

\begin{tabular}{|c|c|c|c|c|c|c|c|c|}
\hline & \multirow[b]{2}{*}{$\mathrm{N}$} & \multirow[b]{2}{*}{ Mean } & \multirow[b]{2}{*}{ Std. } & \multirow[b]{2}{*}{ Std. } & \multicolumn{2}{|c|}{$\begin{array}{l}\text { 95\% Confidence } \\
\text { Mean }\end{array}$} & \multirow[b]{2}{*}{ Minimum } & \multirow[b]{2}{*}{ Maximum } \\
\hline & & & & & Lower Bound & Upper Bound & & \\
\hline Financial & 93 & 79.2258 & 9.41452 & .97624 & 77.2869 & 81.1647 & 58.00 & 107.00 \\
\hline Education & 84 & 88.5714 & 9.62713 & 1.05041 & 86.4822 & 90.6606 & 65.00 & 109.00 \\
\hline IT & 78 & 80.9487 & 8.17805 & .92598 & 79.1049 & 82.7926 & 56.00 & 105.00 \\
\hline Total & 255 & 82.8314 & 9.97038 & 62437 & 81.6018 & 84.0610 & 56.00 & 109.00 \\
\hline
\end{tabular}


Table 3b (ii)

Tests of Anova: Job Security (Education > Finance; Education > IT)

\begin{tabular}{lrrrrr} 
TOT JOB & \multicolumn{7}{c}{ ANOVA } \\
& $\begin{array}{c}\text { Sum of } \\
\text { Squares }\end{array}$ & df & Mean Square & F & Sig \\
\hline Between Groups & 4253.125 & 2 & 2126.562 & 25.523 & .000 \\
Within Groups & 20996.624 & 252 & 83.320 & & \\
Total & 25249.749 & 254 & & & \\
\hline
\end{tabular}

Table 3b (iii)

Tests of Anova: Job Security (Education > Finance; Education > IT)

Multiple Comparisons

Dependent Variable: TOT JOB LSD

\begin{tabular}{llccccc}
\hline & & \multicolumn{2}{c}{$\begin{array}{c}\text { Mean } \\
\text { Difference }\end{array}$} & & & \multicolumn{2}{c}{$95 \%$ Confidence Interval } \\
\cline { 5 - 7 } (I) Industry & $(\mathrm{I})$ Industry & Std. Error & Sig. & Lower Bound Upper Bound \\
\hline \multirow{2}{*}{ Financial Services } & Education & $-9.3456^{*}$ & 1.37398 & .000 & -12.0516 & -6.6397 \\
& IT & -1.7229 & 1.40147 & .220 & -4.4830 & 1.0372 \\
\hline \multirow{2}{*}{ Education } & Financial Services & 9.3456 & 1.37398 & .000 & 6.6397 & 12.0516 \\
& IT & 7.6227 & 1.43531 & .000 & 4.7960 & 10.4494 \\
\hline \multirow{2}{*}{ IT } & Financial Services & 1.7229 & 1.40147 & .220 & -1.0372 & 4.4830 \\
& Education & -7.6227 & 1.43531 & .000 & -10.4494 & -4.7960 \\
\hline
\end{tabular}

* The mean difference is significant at the .05 level.

Table 4 shows the results of the correlation analysis of perception of job security and emotional stability. There was a significant positive correlation of $r=0.403$ between overall perception of job security and emotional stability, which supports Hypothesis 1 of this study. This suggests that employees with high scores on emotional stability, tend to perceive their job as more secure.

Table 4 also shows the correlation coefficients (r), between emotional stability and perception of job security, in four scenarios: all cases, IT industry only, financial services industry only and education industry only. When all cases were taken into account, correlation between emotional stability and perception of job security was significantly positive. It can be inferred that in general, individuals with higher emotional stability will have a stronger sense of perception of job security. The same goes for the correlations between emotional stability in each component of IT, financial services and education industries and perception of job security, which were also significantly positive. However, the strength of association between emotional stability and perception of job security was different in the three industries. Financial services had the strongest association, (r-value of 0.421 ), followed by IT (0.386) and education industries (0.328). Thus the results of this research showed support for both Hypotheses 3 and 4. 
Table 4

Correlation Analysis between Emotional Stability and Perception of Job Security Overall, and in the Different Industries

\begin{tabular}{llccc}
\hline Statistic & $\begin{array}{c}\text { All Cases } \\
(\mathrm{N}=255)\end{array}$ & $\begin{array}{c}\text { Fin } \\
(\mathrm{N}=93)\end{array}$ & $\begin{array}{c}\mathrm{IT} \\
(\mathrm{N}=78)\end{array}$ & $\begin{array}{c}\text { Edu } \\
(\mathrm{N}=84)\end{array}$ \\
\hline Correlation coefficient $(\mathrm{r})$ & $0.403^{* *}$ & $0.421^{* *}$ & $0.386^{* * *}$ & $0.328^{* *}$ \\
\hline
\end{tabular}

$* * \mathrm{p}<.01$

Table 5

Correlation Analysis between Age, Emotional Stability and Perception of Job Security

\begin{tabular}{lccc}
\hline & Age & $\begin{array}{c}\text { Emotional } \\
\text { Stability }\end{array}$ & $\begin{array}{r}\text { Perception of } \\
\text { Job Security }\end{array}$ \\
\hline $\begin{array}{l}\text { Emotional Stability } \\
\begin{array}{l}\text { Perception of } \\
\text { Job Security }\end{array}\end{array}$ & $.136^{* *}$ & 1 & \\
\hline
\end{tabular}

** Correlation is significant at the 0.01 level (2-tailed).

* Correlation is significant at the 0.05 level (2-tailed).

Finally, Table 5 also shows that age, emotional stability and perception of job security are all positively correlated. This suggests that older workers tend to be more emotionally stable and also perceive that their jobs are more secure.

\section{CONCLUSION}

Results of this study suggest that one's emotional stability can affect one's perception of job security in that, employees with stable emotions always perceived job security as high and those with low score on emotional stability perceived job security as low. On average, employees working in the financial services, education and information technology are stable in their emotions and perceive job security as high. However, results suggest that respondents in the education industry are more stable in emotions compared to those in the finance industry. It is not clear whether more emotionally stable people tend to join the education sector rather than finance, or whether workers actually become more emotionally stable as a result of working in the education sector as opposed to the finance sector. Results also suggest that respondents in the education sector perceive job security to be higher compared to those in the finance and IT industries.

Tests of correlation showed that the scores of emotional stability were significantly correlated with perceptions of job security. To control for variances across industries, separate tests of correlation were conducted in each of the sectors and significant correlations between the said variables were found. There is a strongest 
correlation between emotional stability and perception of job security scores in the financial services industry. This suggests that in an industry that is unstable, respondents with higher emotional stability tend to perceive the same environment as more stable than those who have lower emotional stability. The practical implication of this is that workers should undergo training workshops that specialize in enhancing emotional stability, in order for them to manage their perceptions of job security in all these three industries. Finally there are positive correlations between age on the one hand and emotional stability and job security on the other. Managers should therefore encourage the continued tenure of such workers as they are a valuable asset to the organization, and should as far as possible, refrain from taking any actions that would dispel the older workers' positive perceptions regarding the stability of their jobs.

This study is cross-sectional. The findings can only infer association and not the direction nor causality. It can be argued that emotional stability can affect the level of perception of job security. However, it could equally be argued that having a secure job makes one more emotionally stable. This is therefore the proverbial "chicken and egg" situation. This argument, however, could be settled by proposing that these two variables are interdependent.

Another limitation is that the selection of respondents in the study through convenience sampling may have an element of self-selection bias in that researchers approached respondents who appeared friendly and willing to cooperate. However, attempts to reduce the bias have been made to ensure that the racial constitution of the sample approximates that of the general population of Malaysia. Also efforts have been made to ensure that the respondents consisted of people from different levels of higher education and that the sample consisted of approximately equal numbers from the education, finance and IT sectors. An objection can be made that the sample consisted mostly of workers between the ages of 25 to 40 years. However, this is was partly intended, as the purpose of this study is to uncover information that would help the group of people who would continue to remain in work for many more years, rather than those who are about to retire. The findings of this study should not therefore be extended to those in the latter age group.

Finally, this study does not differentiate respondents working in the private sector and government sector. Future researchers should replicate this study by differentiating respondents working in the private sector and government sector. Perhaps people working in the government sector would have perceptions of higher job security compared to people working in the private sector.

\section{REFERENCES}

Antonioni, D., \& Park, H. (2001). The effects of personality similarity on peer ratings of contextual work behaviors. Personnel Psychology, 54 (2), 331-360.

Ashford, S., Lee, C., \& Bobko, P. (1989). Content, causes, and consequences of job insecurity: A theory-based measure and substantive test. Academy of Management Journal, 32, 803-829.

Astrachan, J. H. (1995). Organizational departures: The impact of separation anxiety as studied in a mergers and acquisitions simulation. Journal of Applied Behavioral Science, 31 (1), 3150.

Barrick, M., Dunn, \& Mount, M., Ones. (1995). Relative importance of personality and general mental ability in managers' judgments of applicant qualifications. Journal of Applied Psychology, 80 (4), 500-509.

Barrick, M., Mount, F., Neubert, M., \& Stewart, G. (1998). Relating member ability and personality to work-team processes and team effectiveness. Journal of Applied Psychology, 83 (3), 377. 
Barrick, M. R. Mount, M. K., \& Gupta, R. (2003). Meta-analysis of the relationship between the five-factor model of personality and holland's occupational types. Personnel Psychology, 56 (1), 4574.

Bioscio, M. (2003) Building job security: Strategies for becoming a highly valued contributor. Journal of Healthcare management, 48.

Bradley, M. T., \& Young, M. R. (1998). Social withdrawal: Self-efficacy, happiness, and popularity in introverted and extroverted adolescents. Canadian Journal of School Psychology, 14 (1), 1998, 21-35

Brockner, J., Grover, S. L., Reed, T. F., \& Dewitt. R. L. (1992). Layoffs, job insecurity and survivors' work effort: Evidence of inverted-U relationship. Academy of Management Journal, 35, 413-425.

Buss, D. (1991). Evolutionary Personality Psychology. Annual Review of Psychology, 42, 459.

Caligiuri, P. (2000). The Big Five personality characteristics as predictors of expatriate's desire to terminate the assignment and supervisor-rated performance. Personnel Psychology, 53 (1), 67-88.

Costa, P. T., \& McCrae, R. R. (1992) NEO PI-R Professional manual. Odessa, FL: Psychological Assessment Resources.

Davy, J., Kinicki, A., \& Scheck, C. (1991). Developing and testing a model of survivor responses to layoffs. Journal of Vocational Behavior, 38, 302-317.

De Fruyt, F., Lievens, M., \& Van Dam, K. (2001). Assessors' use of personality traits in descriptions of assessment centre candidates: A Five-Factor Model perspective. Journal of Occupational and Organizational Psychology, 74 (5), 623-635.

Dekker, S. W., \& Shaufeli, W. B. (1995). The effects of job insecurity on psychological health and withdrawal: A longitudinal study. Australian Psychologist, 30, 5763.

Dennis, L., \& Herring, L. (1999). Corporate relocation takes its toll on society. Workforce, 78 (2), 35-37.

Digman, J. M. (1997). Higher order factors of the Big Five. Journal of Personality and Social Psychology, 73, 1246-1256.

Dooley, D., Rook, K., \& Catalano, R. (1987). Job and non-job stressors and their moderators. Journal of Occupational Psychology, 60, 115-132.

Fink, C. A. (1988). Impact of mergers on employees. The Health Care Managers, 7 (1), 59-67.

Flynn, F. J., Chatman, J. A., \& Spataro, S. E. (2001). Getting to know you: The influence of personality on impressions and performance of demographically different people in organizations. Administrative Science Quarterly, 46 (3), 414-445.

Goldberg, L. R. (1990a). An alternative "description of personality": The Big Five factor structure. Journal of Personality and Social Psychology, 59, 1216-1229

Goldberg, L. R. (1992b). The development of markers for the Big-Five factor structure. Psychological Assessment, 4, 26-42

Greenglass, E. R., Burke, R. J., \& Fiksenbaum, L. (2002). Impact of restructuring, job insecurity and job satisfaction in hospital nurses. Stress News, 14 (1), 1-9. 
Greenhalgh, L., \& Rosenblatt, Z. (1984). Job insecurity: Toward a conceptual clarity. Academy of Management Review, 9, 438448.

John, O. P., Donahue, E. M., \& Kentle, R. L. (1991). The Big Five Inventory $4 a$ and 54. Berkeley, Institute of Personality and Social Research. Berkeley CA: University of California.

Judge, T. A., Higgins, C. A., Thoresen, C. J., \& Barrick, M. R. (1999). The Big Five personality traits, general mental ability, and career success across the life span. Personnel Psychology, 52 (3), 621-652.

King, J. (1993). Hold on to Your Head. Computerworld, 27 (32) 85.

Kotter, J. (1983). What Kinds of People Become General Managers. Management Communication Quarterly, 28 (10), 3-18.

Kuhnert, K., Sims, R., \& Lahey, M. (1989). The relationship between perception of job security and employees' health. Group and Organization Studies, 14, 399-410.

Lau, V.P., \& Shaffer, M.A. (1999). Career success: The effects of personality. Career Development International, 4 (4), 225.

Miller, K. (2002). The experience of emotion in the workplace. Modern Office Technology, 15 (4), 571-600.

Mischel, W., Shoda, Y. \& Smith, R. E. (2004) Introduction to personality. San Francisco: John Wiley \& Sons.

Nunnally, J. C. (1978). Psychometric Theory. New York: McGraw-Hill.

Probst, T. M. (2000). Wedded to the job: Moderating effects of job involvement on the consequences of job insecurity. Journal of Occupational Health Psychology, 5, 63-73.
Radding, A. (1991). Higher pay vs. higher education. Computerworld, 25 (7), 82.

Riggio, R. E., \& Taylor, S.J. (2000). Personality and communication skills as predictors of hospice nurse performance. Journal of Business and Psychology, 15 (2), 351359.

Roskies, E., \& Louis-Guerin, C. (1990). Job insecurity in managers: Antecedents and consequences. Journal of Organizational Behavior, 11, 345-359.

Ryckman, R. M. (2004). Theories of Personality. Thomson Wadsworth.

Salgado, J. F. (1997). The Five Factor Model of personality and job performance in the european community. Journal of Applied Psychology, 82 (1), 30-43.

Salgado, J. F. (2003). Predicting job performance using FFM and Non-FFM personality measures. Journal of Occupational and Organizational Psychology, 76(3), 323.

Stevens, C. D., \& Ash, R. A. (2001). Selecting employees for fit: Personality and preferred managerial style. Journal of Managerial Issues, 13(4), 500-517.

Tellegen, (1982) Brief manual for the differential personality questionnaire, unpublished manuscript, University of Minnesota, cited in Jones, G. R. \& George, J. M. (2003) Contemporary Management, 3rd Edition: McGraw-Hill Companies Inc.

Tellegen, A. (1982) Brief Manual for the Differential Personality Questionnaire, unpublished manuscript, University of Minnesota.

Telekom Publications Sdn Bhd, (2002). What is Malaysian Information Industry Directory? Retrieved February 20, 2004 from http://yellowpages.com.my/ product.asp? product $I D=$ industry 
Temple, W. (1992). Human Resource Management: Counterproductive behaviour costs millions. British Journal of Administrative Management, 2, 20.

Tett, R. P., \& Murphy, P. J. (2002). Personality and situations in co-worker preference: Similarity and complementarity in worker compatibility. Journal of Business and Psychology, 17 (2), 223243.

The World Trade Organization (1997). The results of the financial services negotiations under the General Agreement on Trade in Services (GATS). Retrieved February 20, 2004 from http://www.wto.org/ english/tratop e/serv elfinance el finance fback_e.htm
Ugboro, I., \& Obeng, K. (2001). Managing the aftermaths of contracting in public transit organizations: Employee job security,organizational commitment and trust. U.S. Department of Transportation.

US Department of Commerce, (1998). Malaysia: Long term prospects. STAT-USA on the Internet. Retrieved February 20, 2004 from http://strategis.ic.gc.ca/SSG/ da91176e.html

Watson, D., Clark, A. C., \& Harkness, A. R. (1994). Structures of personality and their relevance to psychopathology. Journal of Abnormal Psychology, 103, 18-31. 